\title{
A COMPLETE 3-DIMENSIONAL BLASCHKE-SANTALÓ DIAGRAM
}

\section{RENÉ BRANDENBERG AND BERnARdo GonZÁlez MERino}

Abstract. We present a complete 3-dimensional Blaschke-Santaló diagram for planar convex bodies with respect to the four classical magnitudes: inradius, circumradius, diameter, and (minimal) width in Euclidean spaces.

Mathematics subject classification (2010): Primary 52A10, 52A40; Secondary 52A20.

Keywords and phrases: Inradius, circumradius, geometric inequalities, Blaschke diagram, BlaschkeSantaló diagram, shape diagrams.

\section{REFERENCES}

[1] W. BlaschKe, Eine Frage Über Konvexe Körper, Jahresber. Deutsch. Math. Ver., 25 (1916), 121 125.

[2] T. Bonnesen, W. Fenchel, Theorie der konvexen Körper, Springer, Berlin, 1934, 1974, english translation: Theory of convex bodies, edited by L. Boron, C. Christenson and B. Smith, BCS Associates, Moscow, ID, 1987.

[3] K. BÖröCzKy JR., M. A. Hernández Cifre And G. SAlinas, Optimizing area and perimeter of convex sets for fixed circumradius and inradius, Monatsh. Math., 138 (2003), 95-110.

[4] R. Brandenberg, Radii of convex bodies, Ph. D. thesis, Zentrum Mathematik, Technische Universität München, 2002.

[5] R. BRAndenberg, S. KÖNIG, No dimension-independent core-sets for containment under homothetics, Discrete Comput. Geom., 49 (1) (2013), 3-21.

[6] R. BRANDENBERG, S. KöNIG, Sharpening geometric inequalities using computable symmetry measures, Mathematika, 61 (3) (2015), 559-580.

[7] J. Debayle, J. C. Pinoli And B. Presles, Shape recognition from shadows of 3-D convex geometrical objects, 19th IEEE International Conference on Image Processing (ICIP), 2012, 509-512.

[8] J. Debayle, S. Rivollier And J. C. Pinoli, Adaptive Shape Diagrams for Multiscale Morphometrical Image Analysis, J. Math. Imaging Vis. 2013.

[9] B. V. DeKster, An extension of Jung's theorem, Israel J. Math., 50 (3) (1985), 169-180.

[10] P. Gritzmann, V. KleE, Inner and outer $j$-radii of convex bodies in finite-dimensional normed spaces, Discrete Comput. Geom., 7 (1992), 255-280.

[11] B. González Merino, N. Jonard-Pérez, A pseudometric invariant under similarities in the hyperspace of non-degenerated compact convex sets of $R^{n}$, Topology Appl., 196 (2015), 125-143.

[12] M. A. HERnÁNDEZ CIFRE, Is there a planar convex set with given width, diameter and inradius?, Amer. Math. Monthly, 107 (2000), 893-900.

[13] M. A. HERNÁNDEZ CIFRE, Optimizing the perimeter and the area of convex sets with fixed diameter and circumradius, Arch. Math., 79 (2002), 147-157.

[14] M. A. HeRnÁndez CifRe, E. SAORín, On the roots of the Steiner polynomial of a 3-dimensional convex body, Adv. Geom., 7 (2007), 275-294.

[15] M. A. Hernández Cifre, S. Segura Gomis, The missing boundaries of the Santaló diagrams for the cases $(d, w, R)$ and $(w, R, r)$, Discrete Comp. Geom., 23 (2000), 381-388.

[16] H. Jung, Über die kleinste Kugel, die eine räumliche Figur einschließt, J. Reine Angew. Math., 123 (1901), 241-257.

[17] B. PRESLES, Caractérisation géométrique et morphométrique 3D para analyse d'images $2 D$ de distributions dynamiques de particules convexes anisotropes, $\mathrm{Ph}$. D. Thesis, 2011. 
[18] J. R. SANGwine-YAger, The missing boundary of the Blaschke diagram, Amer. Math. Monthly, 96 (1989), 233-237.

[19] L. SANTALó, Sobre los sistemas completos de desigualdades entre tres elementos de una figura convexa planas, Math. Notae, 17 (1961), 82-104.

[20] R. SChneIder, Convex Bodies: The Brunn-Minkowski Theory, Cambridge University Press, Cambridge, 1993.

[21] P. R. ScotT, Sets of constant width and inequalities, Quart. J. Math. Oxford Ser., 32 (1981), 345-348.

[22] P. Steinhagen, Über die größte Kugel in einer konvexen Punktmenge, Abh. Hamb. Sem. Hamburg, 1 (1921), 15-26.

[23] L. Ting, J. B. Keller, Extremal convex planar sets, Discrete Comput. Geom., 33 (2005), no. 3, 369-393. 